\title{
P-element inserts in transgenic flies: a cautionary tale
}

\author{
MARCEL KAISER, MATTHIAS GASSER, RUEDI ACKERMANN† \& STEPHEN C. \\ STEARNS* \\ Zoology Institute, University of Basle, Rheinsprung 9, CH-4051 Bas/e and †Biocentre, University of Bas/e, \\ Klingelbergstrasse 70, $\mathrm{CH}-4056$ Bas/e, Switzerland
}

\begin{abstract}
The fruitfly, Drosophila melanogaster, can be transfected with P-elements and induced to overexpress a transfected gene whose impact on lifespan can be measured. Here, it is reported that in previous experiments a transfected gene was not expressed. This suggested a new statistical analysis indicating that (1) the size of the insert, the position and the interactions of the insert with the genetic backgrounds into which the P-element are inserted have effects on lifespan similar to those attributed to overexpression; (2) these effects occur without expression of the transfected gene; and (3) effects of interactions with backgrounds and effects of positions are as large as responses to six generations of strong directional artificial selection. Reports of effects of overexpression of transfected genes on lifespan in Drosophila melanogaster may be experimental artefacts. Credible experiments on the phenotypic effects of transgenesis need proper controls for the effects of insert size and position and should estimate the magnitudes of interactions of treatment with genetic backgrounds.
\end{abstract}

Keywords: Drosophila melanogaster, elongation factor, genetic manipulation, lifespan, position effects, size effects.

\section{Introduction}

This paper reports evidence suggesting that experiments testing the effects of transgenesis on phenotypic traits such as longevity, fecundity, age at maturity and body size need controls for size of transgenic insert and estimates of interactions with genetic backgrounds, as well as the well-understood need to control for effects of insert position. The evidence comes from the results of previously published experiments that are reinterpreted here. The reinterpretation was necessitated by new evidence showing that the transfected gene was not expressed. In some cases, the magnitudes of the effects of transgenesis without gene expression were surprisingly large. This paper is a retraction of Stearns et al. (1993) and Stearns \& Kaiser (1993), and it is more than a retraction, for the knowledge that the gene was not expressed allowed us to reanalyse the data to make new points.

Under the assumption that the transfected EF-1 $\alpha$ gene was expressed, our group performed a series of

*Correspondence. E-mail: stearns@wz.unibas.ch experiments to test the effects of the transgene in different genetic backgrounds and insert positions. We concluded that EF- $1 \alpha$ overexpression had no consistent effect on lifespan, because its effects depended strongly on the position of the insert and genetic background (Stearns et al., 1993; Stearns \& Kaiser, 1993). Independently, Shikama et al. (1994) investigated the EF-1 $\alpha$ transgenic flies of Shepherd et al. (1989) at the molecular level. They concluded that the transfected gene was not expressed and therefore that differences in lifespan between EF-1 $\alpha$ and control lines were probably an effect of different insert positions.

If transgenesis and overexpression could be tested reliably, they could lead to genetic engineering of lifespan and promising insights into life history evolution. Before accepting the results of such work, however, we should answer the following questions. Was the transfected gene expressed? (In this case the answer is no.) Were the results an artefact of inserts of different sizes? (They were in part.) Were the effects of insert positions and of interactions of inserts with genetic backgrounds as large as the effects attributed to the overexpression of the transfected gene? (Yes, they were.) 


\section{Background}

Several attempts have been made to demonstrate the existence of longevity-determining genes, either by selection experiments (Luckinbill et al., 1984; Rose, 1984; Arking \& Clare, 1986) or by mutagenesis (Friedman \& Johnson, 1988a,b), but little is known about possible targets for such genes at the cellular or at the molecular level. The use of transgenic animal models (Rubin \& Spradling, 1982) provides a different approach to identifying and characterizing gerontogenes. For example, using transgenic Drosophila, Orr \& Sohal (1994) showed that overexpression of superoxide dismutase (SOD) and catalase in combination results in an increase in lifespan.

Other candidate gerontogenes are those directly involved in protein synthesis. The rate of protein synthesis appears to decline with age in many animal species (Lints \& Bourgois, 1985; Moldave, 1985; Levenbook, 1986; Webster, 1986 - but see Finch, 1990). Experiments performed by Webster (1985) suggested that the age-related decline in protein synthesis in Drosophila might result from the decreased transcription of the EF- $1 \alpha$ gene. The eukaryotic polypeptide chain elongation factor, EF-1 $\alpha$, is a GTP-binding protein that catalyses the binding of aminoacylated tRNAs to the ribosome (Riis et al., 1990). Stimulated by Webster's experiments, Shepherd et al. (1989) asked whether the expression of the EF- $1 \alpha$ gene might contribute to determining the lifespan of Drosophila. They transfected an inbred rosy ${ }^{506}$ line with a P-element carrying the cDNA of the EF- $1 \alpha$ gene under the control of a heat-inducible promoter and the wild-type rosy gene as a selectable marker. The heat shock inducible overexpression of elongation factor $1 \alpha$ appeared to increase lifespan in virgin male fruitflies relative to a control line, which carried essentially the same P-element but without the EF- $1 \alpha$ cDNA and at a different position on the genome.

The effects of insert positions on viability (Mackay, 1989; Mackay et al., 1992) and gene expression (Hazelrigg et al., 1984; Wakimoto et al., 1986; Wilson et al., 1990) are well known. Work on the phenotypic effects of transgenesis should thus check the alternative that transgenesis of inbred Drosophila lines with unexpressed genes carried on P-element vectors inserted at certain positions increases their lifespan. It should also control for the effects of interaction of transgenesis with genetic backgrounds, which are not yet as well appreciated in the literature as position effects. If the impact of transgenesis depends on the genetic background, one cannot predict its effects in the variable, outcrossed backgrounds present in natural populations if one has only worked with a single - often inbred - background. As one goal of transgenesis is genetic therapy, experiments must measure the variation in treatment response with a sample of insert positions and genetic backgrounds to show that the effects claimed are general and occur in wild-type flies.

\section{Materials and methods}

Background and position effects were measured in Drosophila melanogaster transfected with a P-element carrying the gene for a heat-inducible elongation factor $(E F-1 \alpha)$, which should have been expressed at $29^{\circ} \mathrm{C}$, and with a control P-element that did not carry the EF-1 $\alpha$ gene. Two experiments were undertaken, each at two temperatures, $25^{\circ} \mathrm{C}$ and $29.5^{\circ} \mathrm{C}$. All flies measured were as heterozygous as wild flies; the P-element constructs were only present on one of the two diploid third chromosomes.

\section{Construction of the lines}

Large-insert lines consisted of $D$. melanogaster transformed with a P-element construct containing the $r{ }^{+}$marker plus the $F_{1}$ copy of the gene for EF- $1 \alpha$ flanked by initiation and termination sequences for heat shock protein $(11.8 \mathrm{~kb})$. Control lines had been similarly manipulated but lacked the gene for elongation factor; their insert was 16 per cent shorter $(9.9 \mathrm{~kb})$ and at a different position (Shepherd et al., 1989). The large-insert and small-insert lines were obtained from a jumpstart-cross in which P-elements already inserted in the genome jumped to new insert positions (Robertson et al., 1988; Bellen et al., 1989). Balancers ensured that the only surviving flies carried the plasmid on the third chromosome, that the second and third chromosomes were identical, and that the first chromosomes were as identical as a long period of inbreeding would make them (Fig. 1) (The fourth chromosome was not balanced; three-quarters came from the balancer stock, one-eighth from the P-stock and one-eighth from the original $\mathrm{M}$-stock that carried the original EF- $1 \alpha$ insert.) A brother-sister cross between flies with the correct markers yielded flies homozygous for the plasmid construct.

Two experiments were performed, one to test the effects of genetic backgrounds, the other to test the effects of insert positions. For the backgrounds experiment, the test lines were obtained by outcrossing one inbred large-insert (EF-1 $\alpha)$ and one inbred 


\section{Iumpstart Crossing-Scheme}

\section{Cross}

2.Chromosome

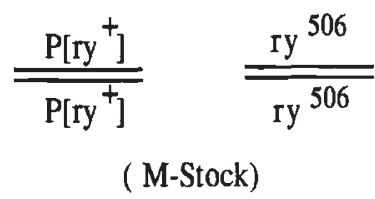

2. Cross

Fig. 1 The jumpstart crossing scheme. Balancers ensured that the only surviving flies carried the plasmid on the third chromosome, that the second and third chromosomes were identical, and that the first chromosomes were as identical as a long period of inbreeding would make them. (The fourth chromosome was not balanced; three-quarters came from the balancer stock, one-eighth from the P-stock and one-eighth from the original M-stock that carried the original EF- $1 \alpha$ insert.) A brother-sister cross between flies with the correct markers yielded flies homozygous for the plasmid construct. In the flies tested, half the genome came from the jumpstart-cross. From Stearns \& Kaiser (1993).

2. Cross
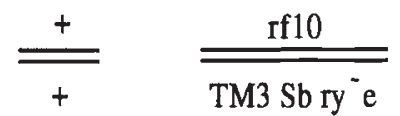

(Balancer-Stock)

stubble, ry $=$ rosy

3. Cross

$\frac{\mathrm{CyO} *}{+}$

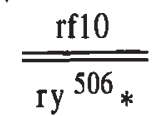

* = new Insertion of the Plasmid curly, non-stubble, $\mathrm{ry}^{+}=$wildtype

4. Cross
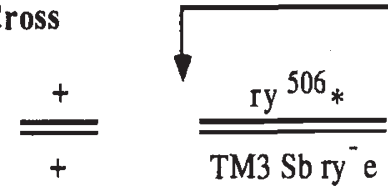

sb, ry ${ }^{+}$, non-curly

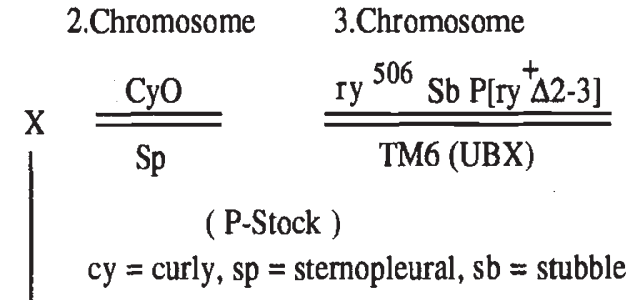

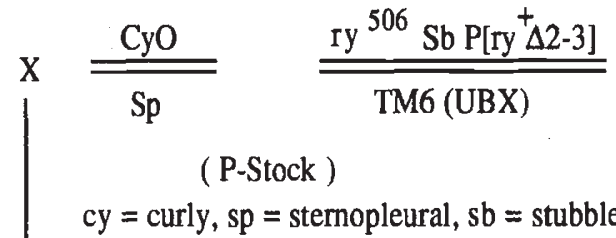


Table 1 A summary of the position of large (Ef-1 $1 \alpha$ ) and small (control) constructs on the chromosome

\begin{tabular}{llll}
\hline & & \multicolumn{2}{c}{$\begin{array}{c}\text { Expression of the } \\
\text { transgene at }\end{array}$} \\
\cline { 3 - 4 } Line & Insert position & $37^{\circ} \mathrm{C}$ & $29^{\circ} \mathrm{C}$ \\
\hline $\mathrm{T}^{*}$ & $79 \mathrm{~F}$ & Yes & No \\
$\mathrm{B}^{*}$ & $61 \mathrm{~A}$ & Yes & No \\
$\mathrm{E}^{*}$ & $94 \mathrm{C}$ & Yes & No \\
$\mathrm{EF} 1 \dagger$ & Centromeric region & Yes & No \\
EF2 & $79 \mathrm{~F}$ & Yes & No \\
EF3 & $96 \mathrm{D}$ & Yes & No \\
EF4 & $96 \mathrm{D}$ & Yes & No \\
EF5 & $99 \mathrm{~B}$ & No & No \\
EF6 & $99 \mathrm{~B}$ & No & No \\
$\mathrm{C} 1$ & $75 \mathrm{C}$ & & \\
$\mathrm{C} 2 \dagger$ & $64 \mathrm{C}$ & & \\
$\mathrm{C} 3$ & $89 \mathrm{~B}$ & & \\
$\mathrm{C} 4$ & $85 \mathrm{D}$ & & \\
$\mathrm{C} 5$ & $61 \mathrm{C}$ & & \\
$\mathrm{C} 6$ & $57 \mathrm{~A}$ second chromosome $\ddagger$ & & \\
\hline
\end{tabular}

Expression of the Ef-1 $\alpha$ transgene was measured in the Drosophila melanogaster lines T, B and E of Shepherd et al. (1989) and in the lines EF1 to EF6 of Stearns et al. (1993).

${ }^{*}$ EF lines made by Shepherd et al. (1989).

tUsed in backgrounds experiment.

$\ddagger$ Two lines were switched in culture after the experiment was carried out and before the positions were determined. The original line was lost.

positions often had traits that differed significantly. Therefore, we treated every insert as though it were a different position, regardless of its macroposition.

\section{Experiments}

In both experiments, there were 24 experimental units [six backgrounds (or positions) $\times$ two temperatures $\times$ two treatments]. Flies were reared from first instar larvae gathered within $8 \mathrm{~h}$ of hatching and kept from that point on at controlled density. Ages were calculated from the midpoint of egg-laying. When experiments had to be run in sequence rather than in parallel, blocks of treatment and control lines were run together, so that differences among blocks were absorbed into the effects of replicates within lines.

\section{Lifespan measurements}

To measure the longevity of virgin males and females, 10 vials per experimental unit were estab- lished with 10 2-day-old flies and given fresh yeast. For mated females, 10 vials per line were established with 10 2-day-old virgin females and 15 2-day-old males. Three times per week the flies were transferred to new vials and the number of dead flies was recorded until the last fly died. In vials with mated females, males were replaced if there were fewer males than females in the vial.

\section{Developmental time and dry weight at eclosion}

Ten vials per line were set up with 12 larvae; 3 days later the number of newly pupated larvae was recorded every $4 \mathrm{~h}$. When all larvae had pupated, an eclosion fractionater (Stearns et al., 1987) collected freshly eclosed flies at 6-h intervals. After sex was determined, they were dried at $50^{\circ} \mathrm{C}$ for $3 \mathrm{~h}$ and weighed to $0.01 \mathrm{mg}$.

\section{Lifetime egg production}

To measure lifetime egg production, 30 vials per line were established with one female and two males per vial. The laying surface was replaced daily by a new one with a drop of fresh yeast. Dead males were removed and replaced by a young virgin male from the same line. The number of eggs laid by each female in $24 \mathrm{~h}$ was counted daily until the last female died. Fecundity early in life was defined as the number of eggs laid per day from the 4th to the 14th day after eclosion. Fecundity late in life was defined as the number of eggs laid from the 15th to the 5 th day before the death of the last female.

\section{Statistical analysis}

Sample sizes for time as pupae, dry weight at eclosion and development time are the number of vials used, with 12 larvae per vial. Sample sizes for lifespan and fecundity are the number of individual flies. The ANOVAS on which the significance values are based were performed with log-transformed data.

Results for genetic backgrounds were analysed by two-way mixed-model factorial ANOVAs with treatment as a fixed effect and background as a random effect, for both temperatures separately. Thus, where $i: 1 \ldots 2$ indexes the fixed-effect treatment $\alpha, j$ : $1 \ldots 6$ denotes random-effect background $b$, and $k$ : $1 \ldots n$ denotes either vials $(n=10$ per line per treatment, temperature and background) or individuals $(n \approx 700$ for fecundity, approximately 2400 for lifespan), the model was: 
$y=\mu+\alpha_{i}+b_{j}+(\alpha \beta)_{i j}+\mathrm{e}_{i j k}$.

When interaction effects were significant, they were used as the denominator for the $F$-tests for significance of the treatment effects (Sokal \& Rohif, 1981, p. 339). Interaction and background effect mean squares were always tested against error mean square. Because error degrees of freedom were much greater than interaction degrees of freedom, denominator mean squares were not pooled when the interaction term was not significant as it would not have changed the conclusions.

Results for insert positions were analysed by mixed-model nested ANOVAs with treatment as a fixed effect and positions nested within treatments as random effects, for both temperatures separately. Where $p$ indicates positions and $p(\alpha)$ indicates positions nested within treatments, the model was:

$y=\mu+\alpha_{i}+p(\alpha)_{i j}+\mathrm{e}_{i j k}$.

Treatment effects were tested with the position mean square; position effects were tested with the error mean square (Sokal \& Rohlf, 1981, p. 283).

\section{Determination of the insert positions}

The salivary gland giant chromosomes were prepared according to Ashburner (1989). The probe, a digoxigenin(DIG)-labelled rosy P-element, was prepared using the Amersham random prime labelling kit. The probe was hybridized according to Ashburner (1989) with minor modifications. The signals were detected using the anti-DIG-alkaline phosphatase Fab fragments of Boehringer (cat. no. 1093 274). After detection of the signal, the chromosomes were counterstained in 2 per cent orcein.

\section{S1 nuclease protection assay}

The $\mathrm{S} 1$ nuclease protection assay was carried out essentially as described in Shikama et al. (1994). Briefly, the RNA probes - antisense RNA1, antisense RNA2 and sense RNA3 (Fig. 2) - were transcribed in vitro from plasmids $\mathrm{pBShsEF}$ and $\mathrm{pBShsEF} / \mathrm{r}$ in the presence of $\left[\alpha^{-}{ }^{32} \mathrm{P}\right] \mathrm{UTP}$ and T7 RNA polymerase (Melton et al., 1984). Total RNA of transgenic flies (Shepherd et al., 1989; Stearns \& Kaiser, 1993; Stearns et al., 1993) was extracted according to Chomczynski \& Sacchi (1987). For each protection experiment, total RNA equivalent to about 5-10 flies was used. Hybridization and S1 nuclease digestion were carried out as described by Giller et al. (1987). The products were separated in
5 per cent polyacrylamide gels. After drying, the gels were exposed to X-ray films.

\section{Results}

Was the EF- $1 \alpha$ transgene expressed? Expression was tested using the $\mathrm{S} 1$ nuclease protection assay described in Shikama et al. (1994). Line T was used by Shepherd et al. (1989) and has been shown to express the transgenic EF- $1 \alpha$ message at $37^{\circ} \mathrm{C}$, but not at $29^{\circ} \mathrm{C}(1994)$. It served as a positive control. In the lines E1 to E6 from the positions experiment, the transgenic message could be detected in the lines $\mathrm{E} 1, \mathrm{E} 2, \mathrm{E} 3$ and $\mathrm{E} 4$ heat shocked to $37^{\circ} \mathrm{C}$, but not in the EF lines E5 and E6 heat shocked to $37^{\circ} \mathrm{C}$ nor in any of the EF lines grown at $29^{\circ} \mathrm{C}$, and it was absent in the control lines (Table 1). The endogenous signal for the EF- $1 \alpha$ mRNA was present in all samples (Fig. 3). Thus, at $29^{\circ} \mathrm{C}$ there was no detect-
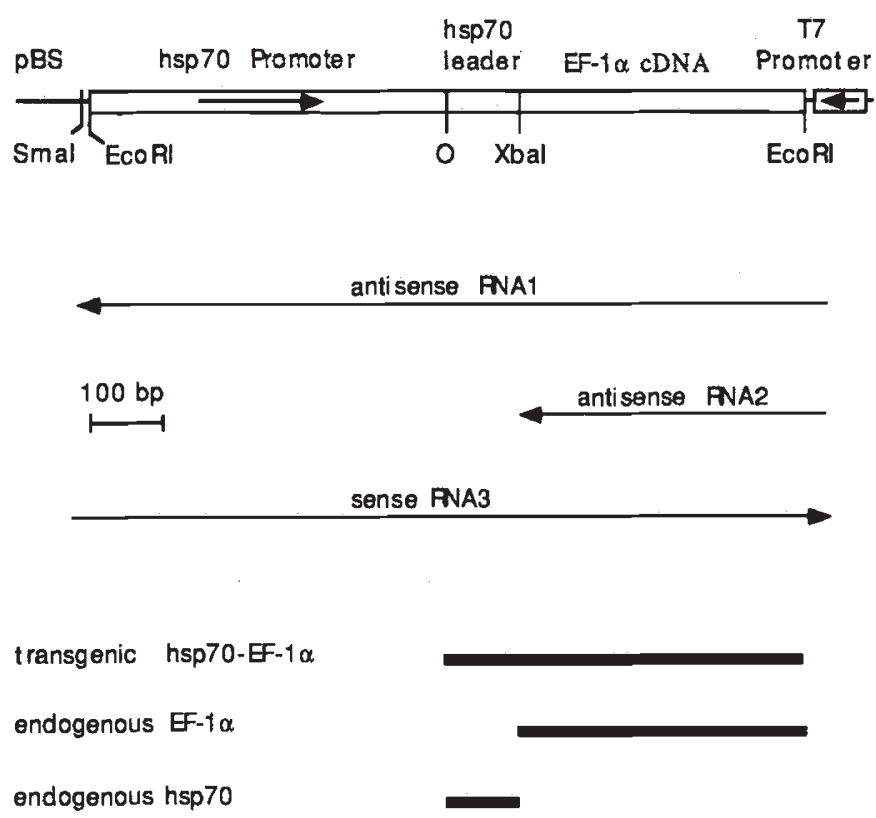

Fig. 2 The map of the pBShsEF plasmid (in the plasmid $\mathrm{pBShsEF} / \mathrm{r}$, the $E c o$ RI insert is in the reverse orientation). pBS, Bluescript plasmid sequences (not drawn to scale). 0 , transcription start site of the hsp70 promoter. The orientation and length of the three RNA probes are shown below. Antisense RNA1 and sense RNA3 have lengths of about 1000 bases, the antisense RNA2 is about 400 bases. The protected fragments in the S1 nuclease protection assay are shown below the probes. Antisense RNA1 protects 500 bases of the transgenic mRNA, 400 bases of the endogenous EF- $1 \alpha$ mRNA and 100 bases of the hsp70 leader of the endogenous hsp70 mRNA. The antisense RNA2 protects 400 bases of the endogenous EF- $1 \alpha$ mRNA. 


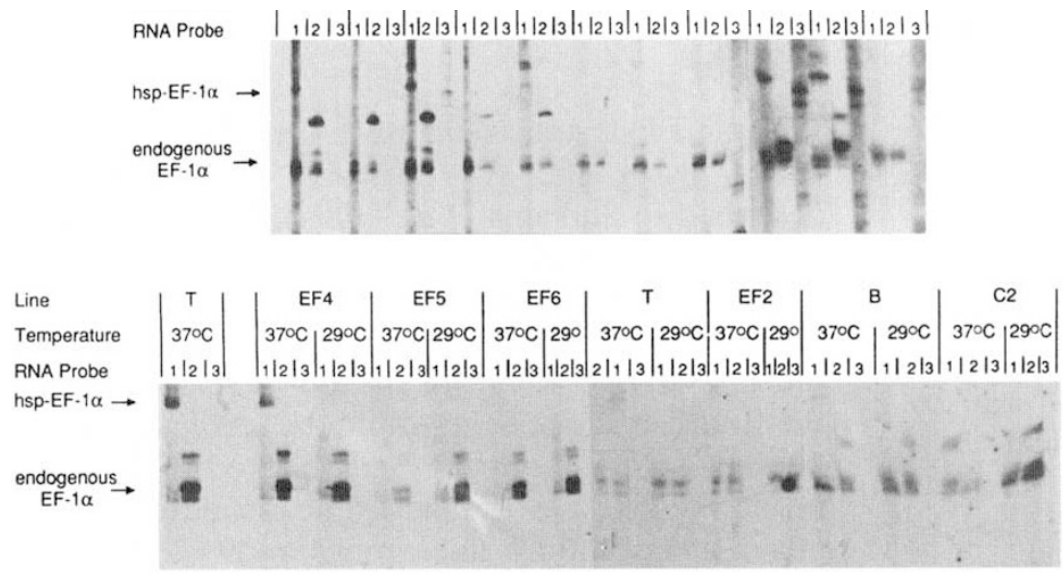

Fig. 3 Expression of the endogenous (lower band) and of the transgenic EF-1 $\alpha$ mRNA (upper band). EF lines were heat shocked to $37^{\circ} \mathrm{C}$ (lanes $37^{\circ} \mathrm{C}$ ) or grown at $29^{\circ} \mathrm{C}$ (lanes $29^{\circ} \mathrm{C}$ ). Total RNA was extracted and probed with antisense RNA1 (lanes 1), hhgb RNA2 (lanes 2), and sense RNA3 (lanes 3). Control flies (C) were also heat shocked to $37^{\circ} \mathrm{C}$ for 1 h. The EF- $1 \alpha$ transgene (arrow) was only seen in strains T, B, E and EF1-EF4 (lanes $1 ; 37^{\circ} \mathrm{C}$ ), in strains EF5 and EF6, and in control flies only the endogenous EF-1 $\alpha$ fragment (arrow) was protected. None of the EF lines expressed the transgene at $29^{\circ} \mathrm{C}\left(\right.$ lanes $\left.1 ; 29^{\circ} \mathrm{C}\right)$. With the RNA probe 2 , the endogenous EF- $1 \alpha$ was detected in all lines and at both temperatures (lanes 2).

Table 2 Representative ANOVAs illustrating (a) effects of backgrounds in which interactions of treatment with background were significant; and (b) effects of size of insert in which variation among positions nested within size were not significant

\begin{tabular}{llllll}
\hline Source & d.f. & SS & MS & $F$-value & $P$-value
\end{tabular}

(a) ANOVA for log-transformed mated female lifespan at $25^{\circ} \mathrm{C}$, background experiment

$\begin{array}{lrrrrr}\text { Size of insert } & 1 & 0.052 & 0.052 & 0.679 & 0.4473 \\ \text { Background } & 5 & 5.885 & 1.177 & 67.871 & 0.0001 \\ \text { Size } \times \text { background } & 5 & 0.385 & 0.077 & 4.443 & 0.0005 \\ \text { Residual } & 1121 & 19.441 & 0.017 & & \end{array}$

(b) ANOVA for log-transformed male development time at $25^{\circ} \mathrm{C}$, positions experiment

\begin{tabular}{lrllll} 
Size of insert & 1 & 0.001 & 0.00150 & 6.493 & 0.029 \\
Position (size) & 10 & 0.002 & 0.00023 & 1.156 & 0.329 \\
Residual & 107 & 0.021 & 0.00020 & & \\
\hline
\end{tabular}

able transgenic EF- $1 \alpha$ message, suggesting that the transgene was not expressed at all or only at an undetectable level in the lifespan experiments. EF- $1 \alpha$ and control lines, therefore, differed mainly in the size and position of the insert; this changed our interpretation of the results.

Size of insert, genetic backgrounds, interactions of inserts with genetic backgrounds. and insert posi- a significant effect on lifespan at both temperatures and irrespective of whether virgin or mated males or females were tested. Lifespan differences ranged from 33 per cent for virgin males at $29^{\circ} \mathrm{C}$ to 76 per cent for mated females at $25^{\circ} \mathrm{C}$. In the backgrounds experiment, virgin males carrying the EF- $1 \alpha$ insert had a 7.2 per cent shorter lifespan than the controls. Backgrounds alwavs differed significantlv in lifesnan. 
Table 3 Magnitude of effects reported as ranges of cell means, i.e. the means for the six backgrounds or insert positions are averaged over the two insert sizes, and the means for the two insert sizes are averaged over the six backgrounds or insert positions

\begin{tabular}{|c|c|c|c|c|c|c|c|}
\hline \multirow[b]{3}{*}{ Experiment } & \multirow[b]{3}{*}{ Trait } & & \multirow{2}{*}{$\begin{array}{l}\text { Background } \\
\text { or position }\end{array}$} & \multirow{2}{*}{\multicolumn{2}{|c|}{ Size }} & \multicolumn{2}{|c|}{$P$-values in ANOvas } \\
\hline & & & & & & \multirow{2}{*}{$\begin{array}{l}\text { Background or } \\
\text { position }\end{array}$} & \multirow{2}{*}{$\begin{array}{l}\text { Background } \times \\
\text { size }\end{array}$} \\
\hline & & $n$ & Range & Range & $\%$ & & \\
\hline
\end{tabular}

(a) Magnitude of effects on lifespan

Backgrounds

$25^{\circ} \mathrm{C} \quad$ Female Mated lifespan (days) Virgin lifespan (days)

Male Virgin lifespan (days)

29.5 ${ }^{\circ} \mathrm{C}$ Female Mated lifespan (days)

Virgin lifespan (days)

Male Virgin lifespan (days)

Positions

$25^{\circ} \mathrm{C} \quad$ Female Mated lifespan (days) 1200

Virgin lifespan (days) 1200

Male Virgin lifespan (days) 1200

$29.5^{\circ} \mathrm{C}$ Female Mated lifespan (days) 1200

Virgin lifespan (days) 1200

Male Virgin lifespan (days)

1112

(b) Magnitude of effects on other life history traits

Backgrounds $25^{\circ} \mathrm{C}$

Females

$\begin{array}{ll}\text { Time as pupae (days) } & 113 \\ \text { Dry weight (mg) } & 117 \\ \text { Development time (days) } & 117 \\ \text { Total fecundity (eggs) } & 347 \\ \text { Early fecundity (eggs) } & 340 \\ \text { Dry weight (mg) } & 118 \\ \text { Development time (days) } & 118\end{array}$

Males

Backgrounds $29.5^{\circ} \mathrm{C}$

Females

$\begin{array}{ll}\text { Dry weight (mg) } & 117 \\ \text { Development time (days) } & 117 \\ \text { Total fecundity (eggs) } & 347 \\ \text { Early fecundity (eggs) } & 340 \\ \text { Late fecundity (eggs) } & 184 \\ \text { Time as pupae (days) } & 116 \\ \text { Dry weight (mg) } & 118 \\ \text { Development time (days) } & 118\end{array}$

Positions $25^{\circ} \mathrm{C}$

Females

Males

$$
\begin{array}{ll}
\text { Time as pupae (days) } & 114 \\
\text { Dry weight (mg) } & 117 \\
\text { Development time (days) } & 117 \\
\text { Total fecundity (eggs) } & 360 \\
\text { Late fecundity (eggs) } & 115 \\
\text { Dry weight (mg) } & 119 \\
\text { Development time (days) } & 119
\end{array}
$$

$\begin{array}{cc}0.208 & \\ 0.042 & 13.8 \\ 0.337 & 3.8 \\ 537.0 & 45.4 \\ 166.4 & 20.0 \\ 0.038 & 17.1 \\ 0.236 & \end{array}$

22.88
15.00
13.00
9.07
12.80
10.87

$\begin{array}{lll}79.9 & +1.18 & +3.0 \\ 28.2 & -0.023 & -0.04 \\ 28.8 & -3.58 & -7.2 \\ 37.2 & +0.73 & +2.7 \\ 57.6 & -0.12 & -0.41 \\ 53.4 & +0.03 & +0.10\end{array}$

$* * * *$
$* * * *$
$* * * *$
$* * * *$
$* * * *$
$* * * *$

$\begin{array}{lc}\text { NS } & * * * \\ \text { NS } & * * \\ * * * & \text { NS } \\ \text { NS } & \text { NS } \\ \text { NS } & * * * * \\ \text { NS } & * * *\end{array}$

$\begin{array}{rrlr}22.90 & 76.4 & +6.99 & +18.0 \\ 15.72 & 41.6 & +5.54 & +12.9 \\ 17.11 & 36.8 & +0.64 & +1.2 \\ 10.60 & 41.2 & +0.350 & +1.1 \\ 9.15 & 33.6 & +2.66 & +8.7 \\ 9.22 & 33.2 & +0.348 & +1.1\end{array}$

$\begin{array}{lc}* * * * & * \\ * * * * & \text { NS } \\ * * * * & \text { NS } \\ * * * * & \text { NS } \\ * * * * & \text { NS } \\ * * * * & \text { NS }\end{array}$

NS

NS

NS

NS

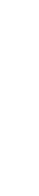


Table 3 Continued

\begin{tabular}{|c|c|c|c|c|c|c|c|c|c|}
\hline \multirow[b]{3}{*}{ Experiment } & \multirow[b]{3}{*}{ Trait } & \multirow[b]{3}{*}{$n$} & \multirow{2}{*}{\multicolumn{2}{|c|}{$\begin{array}{l}\text { Background } \\
\text { or position }\end{array}$}} & \multirow{2}{*}{\multicolumn{2}{|c|}{ Size }} & \multicolumn{3}{|c|}{$P$-values in ANOVAs } \\
\hline & & & & & & & \multirow{2}{*}{$\begin{array}{l}\text { Background or } \\
\text { position }\end{array}$} & \multirow[b]{2}{*}{ Size } & \multirow{2}{*}{$\underset{\text { size }}{\text { Background }} \times$} \\
\hline & & & Range & $\%$ & Range & $\%$ & & & \\
\hline \multirow[t]{3}{*}{ Males } & Time as pupae (days) & 108 & 0.314 & 8.8 & -0.079 & -2.1 & NS & * & \\
\hline & Dry weight (mg) & 118 & 0.023 & 10.0 & -0.008 & -3.4 & NS & * & \\
\hline & Development time (days) & 118 & 0.594 & 7.8 & -0.212 & -2.7 & $* * * *$ & * & \\
\hline
\end{tabular}

Range $=$ largest minus smallest. $\%=100 \times($ largest divided by smallest $)-100$. The ANOvAs on which the significance values are based were performed with log-transformed data. The sign for effects of size indicates the result of increasing the size of the insert. ${ }^{*} P<0.05,{ }^{* *} P<0.01,{ }^{* * *} P<0.001,{ }^{* * * *} P<0.0001$. Sample sizes for time as pupae, dry weight at eclosion and development time are the number of vials used, with 12 larvae per vial. Sample sizes for lifespan and fecundity are the number of individual flies.

several cases (Fig. 4b). In the positions experiment, both females and males carrying the longer insert had a significantly shorter developmental time at $25^{\circ} \mathrm{C}$.

\section{Discussion}

The effects of size of inserts, interactions of inserts with genetic backgrounds, and insert positions are as large as or larger than the effects attributed to the overexpression of transgenes, and they are similar to those achieved in artificial selection experiments after six generations of intense directional selection (Table 4). In the positions experiment, in which the crossing scheme ensured that all flies had the same heterozygous genetic background and the lines differed only in the position of the P-element inserts on the third chromosome, we could estimate the magnitudes of position and size effects reliably. The comparison of these magnitudes with those achieved by directional artificial selection provides a useful baseline against which scientists using transgenic technology can measure the magnitudes of effects achieved by genes that are actually expressed. To be convincing, they should be as large as or larger than the effects we report, and they should be measured with an experimental design adequate to extract the hypothetical signal from the considerable noise caused by the effects we report.

In the experiments of Orr \& Sohal (1994), overexpression of SOD and catalase in combination prolonged lifespan by up to 18 days, whereas either SOD or catalase did not (Orr \& Sohal, 1992, 1993). An effect of the same size was found in our experiments, but the differences in lifespan of our lines were not caused by overexpression of the transgene. (a)

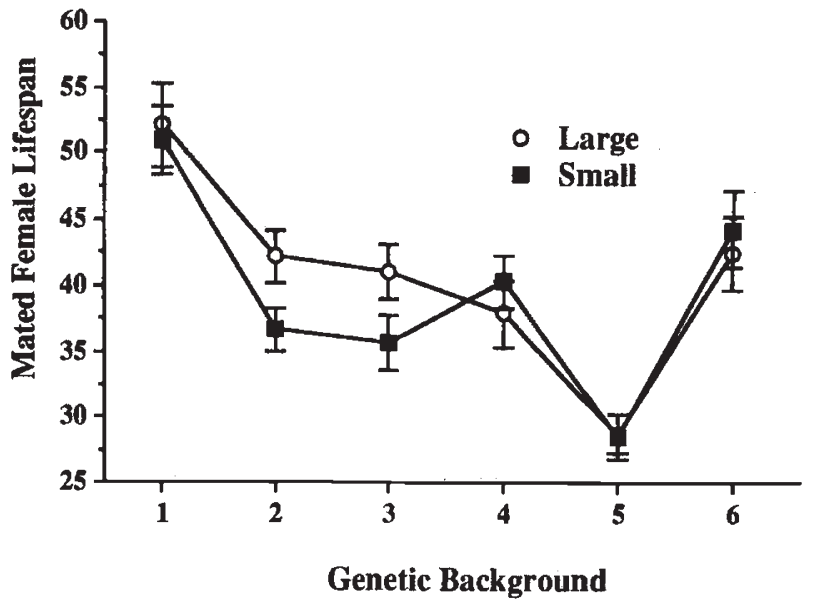

(b)

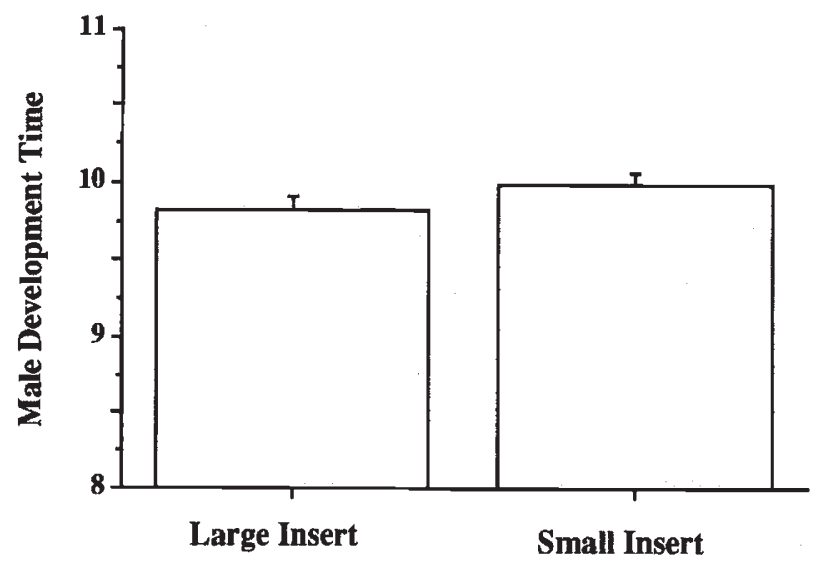

Fig. 4 Plots of the significant effects in the representative ANOVAS reported in Table 2. (a) Background $x$ insert interaction effects for mated female lifespan (days) at $25^{\circ} \mathrm{C}$; (b) effect of size of insert on male development time (days) at $25^{\circ} \mathrm{C}$.

(C) The Genetical Society of Great Britain, Heredity, 78, 1-11. 
Table 4 A comparison of the magnitudes of effects on lifespan achieved by different methods

\begin{tabular}{|c|c|c|c|c|}
\hline Method & $\begin{array}{l}\text { Duration of selection or } \\
\text { gene manipulated or } \\
\text { artefact of insertion }\end{array}$ & Trait & $\begin{array}{l}\text { Magnitude of } \\
\text { effect }\end{array}$ & Reference \\
\hline \multirow[t]{2}{*}{ Selection } & \multirow[t]{2}{*}{ Six generations } & Lifespan, females & 12 days & \\
\hline & & Lifespan, males & 12 days & (1) \\
\hline Transgenesis & Elongation factor $1 \alpha$ & $\begin{array}{l}\text { Lifespan, virgin males } \\
\text { at } 29.5^{\circ} \mathrm{C} \approx 7 \text { days }\end{array}$ & $15 \%$ of lifespan & (2) \\
\hline $\begin{array}{r}\text { Transgenesis and } \\
\text { overexpression }\end{array}$ & $\begin{array}{l}\text { Superoxide dismutase } \\
\text { and catalase }\end{array}$ & Lifespan, virgin males & Up to 18 days & (3) \\
\hline \multirow{5}{*}{$\begin{array}{l}\text { Artefact of } \\
\text { P-element insert } \\
\text { (this study) }\end{array}$} & \multirow[t]{2}{*}{ Genetic background } & Lifespan, mated females & $\begin{array}{l}23 \text { days at } 25^{\circ} \mathrm{C} \\
9 \text { days at } 29.5^{\circ} \mathrm{C}\end{array}$ & \\
\hline & & Lifespan, virgin males & $\begin{array}{l}13 \text { days at } 25^{\circ} \mathrm{C} \\
11 \text { days at } 29.5^{\circ} \mathrm{C}\end{array}$ & \\
\hline & \multirow[t]{2}{*}{ Insert position } & Lifespan, mated females & $\begin{array}{l}23 \text { days at } 25^{\circ} \mathrm{C} \\
11 \text { days at } 29.5^{\circ} \mathrm{C}\end{array}$ & \\
\hline & & Lifespan, virgin males & $\begin{array}{l}17 \text { days at } 25^{\circ} \mathrm{C} \\
9 \text { days at } 29.5^{\circ} \mathrm{C}\end{array}$ & \\
\hline & Size of insert & Lifespan, mated females & 7 days at $25^{\circ} \mathrm{C}$ & \\
\hline
\end{tabular}

(1) Zwaan (1993).

(2) Shepherd et al. (1989).

(3) Orr \& Sohal (1994).

The observation that the transfected EF-1 $\alpha$ gene was not expressed at $29^{\circ} \mathrm{C}$ is surprising, for the hsp 70 promoter is leaky at $25^{\circ} \mathrm{C}$ and should promote strong transcription at $29^{\circ} \mathrm{C}$. It seems that in all lines the transformed EF-1 $\alpha$ gene integrated at chromosomal locations at which gene expression may have been reduced or even suppressed at $29^{\circ} \mathrm{C}$. This could explain the complete failure in inducing expression of the transgenic EF- $1 \alpha$ in the EF lines E5 and E6. In an attempt to establish transgenic mice that overexpress EF- $1 \alpha, 10$ lines that had incorporated the transgene were tested for transgene expression. None of these lines showed expression of the transfected gene (R. Ackermann, unpublished results). There is evidence that EF- $1 \alpha$ could exert negative effects when overexpressed. Tatsuka et al. (1992) have shown in cell cultures that transfection of cells with EF- $1 \alpha$ enhances the probability of transformation. Flies and mice that overexpressed EF-1 $\alpha$ might, therefore, have died early in development, leaving only EF lines that do not express the transgene. Thus, the effects of the transgene on lifespan in our EF and $\mathrm{C}$ lines cannot be explained by overexpression of EF-1 $\alpha$; we believe they are caused by the different insert positions and size.

Several problems should not be forgotten in lifespan studies performed with genetically engineered organisms. To be sure that the effect on lifespan is owing to the engineered gene, the expression of the gene must be measured. The best measure would be an assay of the activity of the gene product, for the amount of mRNA and protein does not necessarily reflect the activity of a gene. Shikama et al. (1994) have shown that the catalytic activity of EF- $1 \alpha$ decreases more rapidly with age than does the amount of the protein, but they found no difference between EF- $1 \alpha$ and control lines.

That the effect of the P-element position, size of insert and the background can be as large as the effect of a transgene is surprising. Experiments undertaken with transfected flies that do not control for the effects of insert sizes and positions and genetic backgrounds cannot be regarded as reliable. The insertion of unexpressed P-elements into the germline of fruit flies can have large effects on fitness components, including lifespan, as large as those induced by strong, artificial selection for six generations.

Although most people working on transgenic organisms appreciate the importance of good controls for position effect achieved by working with inducible promoters and with a sample of inserts made at several positions, many do not yet appreciate the effects of inserts of different sizes, and they usually ignore the variation that can be induced by genetic backgrounds. Interactions with genetic back- 
grounds are not trivial when one is testing hypotheses about the factors determining lifespan in natural populations. If most of the effects detected in inbred transgenic organisms disappear when tested in outbred lines as a result of background by treatment interaction effects, which are frequent in our results (see Table 3), that is important for two reasons. First, if a particular effect only appears in one genetic background, it is not general. Generality can only be established by demonstrating that the treatment has consistent effects across a large enough sample of genetic backgrounds to permit the conclusion that it would probably have an effect in almost any genetic background - in any outbred sexually reproducing organism. Secondly, many transgenic manipulations are carried out with a view towards some form of genetic 'therapy' - in this case, extending lifespan. If the therapy only works in some genetic backgrounds and not in others, that should be understood and reported.

The present authors have reported such effects previously (Stearns \& Kaiser, 1993). However, what is new here is the knowledge that the transfected EF- $1 \alpha$ gene was not expressed in any of our experiments, which simplified the statistical analysis and changed the interpretation. The effects reported here, caused by unexpressed P-elements of two different sizes inserted into different positions and genetic backgrounds, are potentially confounding factors that pose a serious challenge to experimental design. Valid control inserts must be the same size and at the same position as treatment inserts. Before claims are issued that a genetic therapy has been found, the interactions of transgenesis with a convincing sample of genetic backgrounds should have been tested.

\section{Acknowledgements}

Thanks to John Shepherd and Walter Gehring for sharing data and their stocks with us. EF-1 $\alpha$ expression and the position of the P-element insert were determined in Christine Brack's former lab.; we are very grateful for her hospitality and her helpful discussions. We thank Anni Mislin and Hanni Zingerli for their precise and reliable work in the laboratory. Our research was supported by Schweizerischer Nationalfonds Grants (3.643.0.87 and 31-28511.90) to S.C.S.

\section{References}

ARKING, R. AND CLARE, M. 1986. Genetics of aging: Effective selection for increased longevity in Drosophila. In:
Collatz, K.-G. and Sohal, R. S. (eds) Insect Aging: Strategies and Mechanism, pp. 217-236. Springer Verlag, Berlin.

ASHBURNer, M. 1989. Drosophila, pp. 1053-1054. Cold Spring Harbor Laboratory Press, New York.

BELLEN, H. J., O'KANE, C. J., WILSON, C., GROSSNIKLAUS, U., PEARSON, R. K. AND GEHRING, W. J. 1989. P-element mediated enhancer detection: a versatile method to study development in Drosophila. Genes Devel., 3, 1288-1300.

CHOMCZYNSK1, P. AND SACCH1, N. 1987. Single-step method of RNA isolation by acid guanidinium thiocyanatephenol-chloroform extraction. Analyt. Biochem., 162, $156-159$.

FINCH, C. E. 1990. Longevity, Senescence, and the Genome. University of Chicago Press, Chicago.

FRIEDMAN, D. B. AND JOHNSON, T. E. 1988a. A mutation in the age-1 gene in Caenorhabditis elegans lengthens life and reduces hermaphrodite fertility. Genetics, 118, 75-86.

FRIEDMAN, D. B. AND JOHNSON, T. E. 1988b. Three mutants that extend both mean and maximum life span of the nematode, Caenorhabditis elegans, define the age-1 gene. J. Gerontol., 43, B102-B109.

GILler, T., BRUNNER, L., PICK, L. AND BRACK, C. 1987. A homologous in vitro system to analyse transcription of a mouse immunoglobulin $\mu$ heavy-chain gene. Eur. $J$. Biochem., 172, 679-685.

HAZElRigG, T., LEVIS, R. AND RUBIN, G. M. 1984. Transformation of white locus DNA in Drosophila: dosage compensation, zeste interaction and position effects. Cell, 36, 469-481.

LEVENBoOK, L. 1986. Protein synthesis in relation to insect aging: An overview. In: Collatz, K.-G. and Sohal, R. S. (eds) Insect Aging: Strategies and Mechanism, pp. 200-206. Springer Verlag, Berlin.

LINTS, F. A. AND BOURGols, M. 1985. Aging and lifespan in insects with special regard to Drosophila: review 1982-84. Rev. Biol. Res. Aging, 2, 61-84.

LUCKINBILl, L. S., ARKING, R., CLARE, M. J., CIROCCO, W. C. AND BUCK, s. A. 1984. Selection for delayed senescence in Drosophila melanogaster. Evolution, 38, 996-1003.

MACKAY, T. F. C. 1989. Transposable elements and fitness in Drosophila melanogaster. Genome, 31, 284-295.

MACKAY, T. F. C., LYMAN, R. F. AND JACKSON, M. S. 1992. Effects of $\mathrm{P}$ element insertions on quantitative traits in Drosophila melanogaster. Genetics, 130, 315-332.

MELTON, D. A., KRIEG, P. A., REBAGLIATI, M. R., MANiATIS, T., ZINN, K. AND GREEN, M. R. 1984. Efficient in vitro synthesis of biologically active RNA and RNA hybridization probes from plasmids containing a bacteriophage SP6 promoter. Nucl. Acids Res., 12, 7035-7056.

Moldave, K. 1985. Eucaryotic protein synthesis. Ann. Rev. Biochem., 54, 1109-1149.

ORR, w. C. AND SOHAL, R. s. 1992. The effects of catalase gene overexpression on life span and resistance to oxidative stress in transgenic Drosophila melanogaster. Arch. Biochem. Biophys., 297, 35-41.

ORR, w. C. AND SOHAL, R. s. 1993. Effect of $\mathrm{Cu}-\mathrm{Zn}$ super- 
oxide dismutase overexpression on life span and resistance to oxidative stress in transgenic Drosophila melanogaster. Arch. Biochem. Biophys., 301, 34-40.

ORR, w. C. AND SOHAL, R. s. 1994. Extension of life-span by overexpression of superoxide dismutase and catalase in Drosophila melanogaster. Science, 263, 1128-1130.

RIIS, B., RATTAN, S. I. S., CLARK, B. F. C. AND MERRICK, W. C. 1990. Eukaryotic protein elongation factors. Trends Biochem. Sci., 15, 420-424.

ROBERTSON, H. M., PRESTON, C. R., PHILLIS, R. W., JOHNSONSCHLITZ, D. W., BENZ, w. K. AND ENGELS, w. R. 1988. A stable genomic source of $\mathrm{P}$ element transposase in Drosophila melanogaster. Genetics, 118, 461-470.

ROSE, M. R. 1984. Laboratory evolution of postponed senescence in Drosophila melanogaster. Evolution, 38, $1004-1010$.

RUBIN, G. M. AND SPRADLING, A. C. 1982. Genetic transformation of Drosophila with transposable element vectors. Science, 218, 348-353.

SHEPHERD, J. W. C., WALLDORF, U., HUG, P. AND GEHRING, w. J. 1989. Fruit flies with additional expression of the elongation factor EF-1 $\alpha$ live longer. Proc. Natl. Acad. Sci. U.S.A., 86, 7520-7521.

SHIKAMA, N., ACKERMANN, R. AND BRACK, C. 1994. Protein synthesis elongation factor EF-1 $\alpha$ expression and longevity in Drosophila melanogaster. Proc. Natl. Acad. Sci. U.S.A., 91, 4199-4203.

SOKAL, R. R. AND ROHLF, F. J. 1981. Biometry, 2nd edn. W. H. Freeman, San Francisco.

STEARNS, S. C. AND KAISER, M. 1993. The effects of enhanced expression of elongation factor EF- $1 \alpha$ on lifespan in Drosophila melanogaster. IV. A summary of three experiments. Genetica, 91, 167-182.

STEARNS, S. C., DIGGELMANN, T., GEBHARDT, M., BACHMANN, H. AND WECHSLER, R. 1987. A device for collecting flies of precisely determined post-hatching age. Drosoph. Inf. Serv. 66, 167-169.

STEARNS, S. C., KAISER, M. AND HILLESHEIM, E. 1993. Effect on fitness components of enhanced expression of elongation factor EF- $1 \alpha$ in Drosophila melanogaster. I. The contrasting approaches of molecular and population biologists. Am. Nat., 142, 961-993.

TATSUKA, M., MiTSUl, H., WADA, M., NAGATA, A., NOJiMA, H. AND OKAYAMA, H. 1992. Elongation factor-1 $\alpha$ gene determines susceptibility to transformation. Nature, $\mathbf{3 5 9}$, 333-336.

WAKIMOTO, B. T., KALFAYAN, L. J. AND SPRADLING, A. C. 1986. Developmentally regulated expression of Drosophila chorion genes introduced at different chromosomal positions. J. Mol. Biol., 187, 33-45.

WEBSTER, G. C. 1985 . Protein synthesis in aging organisms. In: Sohal, R. S., Birnbaum, L. S. and Cutler, R.G. (eds) Molecular Biology of Aging: Gene Stability and Gene Expression, pp. 263-289. Raven Press, New York,

WEBSTER, G. C. 1986. Effect of aging on the components of the protein synthesis system. In: Collatz, K.-G. and Sohal, R. S. (eds) Insect Aging: Strategies and Mechanism, pp. 207-216. Springer Verlag, Berlin.

Wilson, C., BELlen, H. J. AND GEHRING, w. J. 1990. Position effects on eukaryotic gene expression. Ann. Rev. Cell Biol., 6, 679-714.

ZWAAN, s. 1993. Genetical and Environmental Aspects of Ageing in Drosophila melanogaster: an Evolutionary Perspective. PhD thesis, University of Groningen. 